\title{
Emerging Perspectives on Automobilities in Non-Urban Australia: A context for Cruising Country
}

\author{
Ursula Frederick and Lisa Stefanoff
}

Since the early twentieth century, motor vehicles of all descriptions have been central characters in the settlement, governance and representation of Australia. They have been, and remain, objects of desire and exchange, characters in subsistence, ceremonial and market economies, sites of projective identification and spaces of distinctive social experience. Local and national spaces, time, histories and identities are reshaped in and through our car cultures. Represented in paintings, sculpture, films, literature, music, ceremony and other media, vehicles and the roads they travel communicate closely with the aesthetic spirits of modernity and its postmodern discontents. This issue of Humanities Research sets out to explore some of the key conjunctures of Australian nonurban automobility - intercultural exchange and communication, power and social transformation - from the vantage points of history, cultural studies, art history, anthropology, and visual art. The authors in this volume examine the ways in which car cultures in non-urban Australia produce social relationships between car owners, drivers, passengers, their families, and their observers through the mediating forms and forces of moving vehicles, petrol, bitumen, and the inevitable debris of car wreckages and ruins. In this respect, the analyses collected here provide fresh insights into what anthropologist Daniel Miller has called 'the humanity of the car'. ${ }^{1}$

The idea for this volume emerged as a coda to a symposium, a photography exhibition and a screening program-Cruising Country: Automobilities in nonurban Australia - held at the ANU Centre for Cross-Cultural Research in 2005 (26-28 May). ${ }^{2}$ The symposium canvassed car-focused histories, artworks, documentary film, ethnography, cultural analysis and personal storytelling offered by researchers, artists, filmmakers, and Aboriginal elders. As the producers of that event, we conceived the term 'cruising country' to conjure and capture the affective experiences of being automobile on a national map where 'country' is a multivalent post-colonial concept of enduring Aboriginal space and place; country is overwritten by tracks, roads, highways and the

1 Miller, Daniel 2001, Car Cultures, Berg, Oxford, p. 2.

2 <http://www.anu.edu.au/culture/cruising >, viewed 2 June 2011. 
myriad 'cruising' journeys they have enabled, from the 'first contact' encounters of desert patrol officers to family trips, from rallies to 'grey nomad' adventures, artists' research routes and cinematic narratives (to name only a few that were featured at the 2005 event).

Where once the analysis of car culture began in the driveways and petrol stations of cities and suburbs, the Cruising Country project has turned over the engine to confront another set of stories - those we call the 'non-urban'. Here, motor vehicles are seen making tracks across 'the frontier' of the post-colonial nation and carrying research across other romantic tropes of exploration that require ongoing critical attention in the analysis of post-colonial settler societies. The non-urban focus of our theme reframes notions of distance and 'remoteness', and repositions the desert, the bush and suburban fringes at the centre of narratives of Australian automobility.

The exponential growth of Australian road construction in the twentieth and twenty-first centuries is intertwined with structural transformations of an economy balancing land-based primary industries (and the regional expansion that followed these developments) with domestic manufacturing and commodity importation and circulation of ever more goods beyond major metropolitan zones. Domestic and regional industrialisation of automotive manufacturing, the normalisation of car ownership, the fading of rail travel as mass experience and the development of a diversified market of road-based tourist travel have solidified automobility as contemporary Australian habitus. Given the ubiquity and normalisation of car travel as the primary everyday habit of mobility in postwar First-World countries, it is actually surprising that there has not been more humanities and social science research into the varieties of automobile experience in Australia, or elsewhere. Like the Cruising Country symposium, this collection of essays appears at an important time. Global concerns and contestations over climate change, resource depletion and the geopolitical status of automobile production, infrastructure and use make work on automobilities an increasingly relevant field of twenty-first-century research.

Over the course of the past decade, research focused on the role of the car in contemporary society and culture has intensified. Providing some attempt to encompass the disciplinary breadth of this research and the vast scope of the automobile's impression in our lives, sociologists John Urry and Mimi Sheller spearheaded the concept of 'a system of automobility'. ${ }^{3}$ Underpinning their notion of a 'car system' is an effort to grasp 'how its awesome pattern

3 Sheller, Mimi 2004, 'Mobile publics: beyond the network perspective', Environment and Planning D: Society and Space, vol. 22, no. 1 (February), pp. 39-52; Sheller, Mimi and Urry, John 2003, 'Mobile transformations of "public" and "private" life', Theory, Culture and Society, vol. 20, no. 3, pp. 107-25; Sheller, Mimi and Urry, John 2000, 'The city and the car', International Journal of Urban and Regional Research, vol. 24, no. 4, pp. 737-57; Hannam, K., Sheller, Mimi and Urry, John 2006, 'Mobilities, immobilities and moorings', 
of path dependency was established and exerted a particularly powerful and self-expanding pattern of domination across the globe'. ${ }^{4}$ This dominance must also be considered in terms of an unevenly deployed technological force that is sometimes also violently exercised. Just as authors in this volume point to the role automobility has played in colonising Australian terrain, scholars also point to the social inequalities that car cultures have generated. ${ }^{5}$

Although not necessarily always urban in its intent, automobilities research has tended to focus on the city, the suburban and the high-speed motorways that link these spaces. ${ }^{6}$ Importantly, automobilities research, much of which has taken place in Europe, has been shaped by the work of cultural geographers and their attention to places and communities as well as spatial corridors, such as the autobahn and the M5. ${ }^{7}$ In contrast, relatively little attention has been paid to automobility as it occurs in less urbanised environments - clearly one distinctive area where Australian scholarship offers unique promise. ${ }^{8}$

Our application of the term 'automobilities' is aimed at enfolding the car, the road and the human body into an integrated interdisciplinary field of research, in recognition of the fact that there are only intersections and overlaps and no clear boundaries between these elements. Our adoption of the term signals our recognition of the complexities of car cultures as a set of material and intangible forces, instruments and practices that shape our ways of being in the world. A central tenet of the automobilities paradigm is, after all, an acknowledgment that one need not drive or own a car to be deeply enmeshed in an automobilised world.

In 2005 we were in a position to observe the then steady, if thin, flow of humanities and social science research with analyses of motor vehicles at their centre. ${ }^{9}$ Within Australia, cars and automobility had been examined primarily

[Editorial Introduction], Mobilities, vol. 1, no. 1 (March), pp. 1-22; Sheller, M. and Urry, J. (eds) 2006, Environment and Planning. A. Special Issue: Materialities and Mobilities, including 'Editorial Introduction: "The new mobilities paradigm"”, vol. 38, pp. 207-26.

4 Urry, John 2004, 'The "system" of automobility', Theory, Culture \& Society, vol. 21, nos 4-5 (October), p. 25.

5 Seiler, Cotten 2008, Republic of Drivers: A cultural history of automobility in America, University of Chicago Press, Chicago.

6 Sheller and Urry, 'The city and the car'; Butcher, Melissa and Thomas, Mandy 2003, 'Cruising', in Melissa Butcher and Mandy Thomas (eds), Ingenious: Emerging youth cultures in urban Australia, Pluto Press, Sydney. 7 Thrift, Nigel 2004, 'Driving in the city', Theory, Culture \& Society, vol. 21, nos 4-5, pp. 41-59; Merriman, Peter 2007, Driving Sp'aces: A cultural-historical geography of England's M1 Motorway, Blackwell, Malden, Mass., and Oxford, UK.

8 Simpson, Catherine 2006, 'Antipodean automobility and crash: treachery, trespass and transformation of the open road', Australian Humanities Review, nos 39-40 (September).

9 Cohan, S. and Hark, I.R. (eds) 1997, The Road Movie Book, Routledge, London and New York; Brottman, Mikita 2001, Car Crash Cultures Palgrave, New York; Miller, Car Cultures; Wollen, Peter and Kerr, Joe 2002, Autopia, Reaktion, London; Davison, Graeme 2004, Car Wars, Allen and Unwin, Crows Nest. 
through the lenses of historical analysis, ${ }^{10}$ film studies ${ }^{11}$ and transport studies and through various genres of non-fiction travel writing. ${ }^{12}$ In many ways, the purpose of Cruising Country was to harness this distributed discourse within the context of the Australian experience. In her review of the Cruising Country symposium, Catherine Simpson noted the contemporary relevance of this approach, recognising that it 'gave voice to a diverse range of vehicular-based knowledges, narratives and experiences which, up until now, have been given little critical attention at a scholarly level' ${ }^{\prime 3}$ It is in keeping with the spirit of the 2005 event and its unfolding of a new map for research and writing that the papers assembled here provide a renewed set of perspectives on the theme of Australian automobility beyond our national urban heartlands.

While the 'system of automobility' has proven to be a useful framework for motivating interdisciplinary exchange on car-related research, it has not gone unchallenged. ${ }^{14}$ One of the shortcomings, according to cultural political economist Matthew Paterson, is 'a tendency to fall back on a phenomenological account of automobility, to focus on automobility as a feature of individual daily lives' ${ }^{15}$ Paterson is concerned that a phenomenology of automobility risks normalising an association between human freedoms and driving cars; ${ }^{16}$ tropes of liberty are easily naturalised through the iconicity of the basic capacities of cars and roads to carry riders into hitherto inaccessible places. Certainly, the trope of the automobile as a vehicle of individual liberty has been granted a lot

10 Knott, John W. 1994, 'Speed, modernity and the motor car: the making of the 1909 Motor Traffic Act in New South Wales', Australian Historical Studies, vol. 26, no. 103 (October), pp. 221-41; Knott, John W. 2000, "'The conquering car": technology, symbolism and the motorisation of Australia before World War II', Australian Historical Studies, vol. 31, no. 114 (April), pp. 1-26; White, Richard with Ballard, S., Bown, I., Lake, M., Leehy, P. and Oldmeadow, L. 2005, On Holidays: A history of getting away in Australia, Pluto Press Australia, Sydney.

11 For example, Morris, Meaghan 1998, 'White panic or Mad Max and the sublime', in Chen Kuan-Hsing (ed.), Trajectories: Inter-Asian cultural studies, Routledge, London, pp. 239-62; Clarsen, Georgine 2002, 'Still moving: Bush Mechanics in the Central Desert', Australian Humanities Review, viewed 10 June 2011, <http:// www.australianhumanitiesreview.org/archive/Issue-March-2002/clarsen.html>; Tranter, K. 2003, 'Mad Max: the car and Australian governance', National Identities, vol. 5, no. 1, pp. 68-81; Venkatasawiny, R., Simpson, C. and Visosevic, T. 2001, 'From sand to bitumen, from bushrangers to "bogans": mapping the Australian road movie', Journal of Australian Studies, vol. 70, pp. 75-84.

12 For example, Beadell, Len 1969, Too Long in the Bush, Rigby, Adelaide; Birtles, Dora c. 1947, The Overlanders, Virago, London; Horwitz, Tony 1987, One for the Road: A hitchhiker's outback, Harper \& Row, Sydney; Muecke, Stephen 1997, No Road: Bitumen all the way, Fremantle Arts Centre Press, South Fremantle, WA.

13 Simpson, Catherine 2005, 'Symposium report: Cruising Country: Automobility in Non-Urban Australia', SCAN: Journal of Media Arts, 2005-09-05, p. 1, viewed 5 December 2008, <http://scan.net.au/scan/magazine/ print.php?journal_id $=43>$

14 For a discussion of perceived gaps in the paradigm, see, for example, Bohm, S., Jones, C., Land, C. and Paterson, M. (eds) 2007, Against Automobility, Blackwell, Oxford; and for a provocation on the use of the term, see Ker, Ian and Tranter, Paul 1997, 'A wish called wander: reclaiming automobility from the motor car', World Transport Policy \& Practice, vol. 3, no. 2, pp. 11-16.

15 Paterson, Matthew, 2007, Automobile Politics, Ecology and Cultural Political Economy, Cambridge University Press, Cambridge, p. 26.

16 Paterson is certainly not alone in examining the link between the ideology of freedom and driving. For a particularly valuable contribution on this point, see Seiler, Cotton 2008, Republic of Drivers. 
of mileage in popular media - from literature and cinema to broadcast, print and online advertising. ${ }^{17}$ The freedom trope is, moreover, dominant and instructive in the cultures of automobile modernity across multiple national contexts and in the production of tremendous consumer desire. ${ }^{18}$

And yet, car trips are unquestionably key sites of contemporary social experience. In this sense, they offer temporary, if familiar, parameters for individual and social imagination. Car trips are sites for the production of individual and communal memory. They are ground, figure and eventually memory places of travel stories anchored in a range of kinaesthetic experiences: listening to radio, recorded music, or engine sounds, envisioning the world as motion and velocity through windows and mirrors, feeling and smelling the close physical presence of other bodies and objects, tasting and sharing meals and engaging in tight communication. Representations of these affective dynamics abound in the road-movie genre. In the Australian case, who can forget the tense containment of cultural, class and gender differences, the conflict, excessive behaviour and rough connectedness of the riders travelling a road to possibly nowhere in Philip Noyce's 1977 debut Australian feature film, Backroads?

Without losing sight of the ideological drivers of the liberty trope, and acknowledging the importance of examining the political economies of automobilities, we believe that lived everyday experiences and affective representations of the cultural 'systems' of cars, roads and automobile travel remain fundamental grounds on which comparative research in this field should evolve. The 2002 volume Car Cultures, from Berg's 'Materializing Culture' series, is pivotal in this respect insofar as it approaches and surveys the values of cars as key players in a variety of locally lived worlds. The authors collected in this text approach cars as aesthetic, utilitarian, social and cultural objects, sites and representations with meanings generated across intersecting regimes of value. Two essays in this collection describing the car cultures of Australian desert worlds introduce readers to some of the non-urban Australian automobilities context that Cruising Country elaborates. ${ }^{19}$

Australian studies scholars are well positioned to offer the growing global automobilities dialogue a set of distinctive perspectives through a focus on non-urban geographies. Geographical and social tensions between Australia's south-eastern seaboard population concentrations and the country's sparsely dispersed 'regional' and 'remote' cities, towns, communities and pastoral

17 Jack Kerouac's 1957 novel, On the Road, and Dennis Hopper's 1969 film, Easy Rider, are iconic North American articulations of this postwar fantasy.

18 Arguably, this trope persists as the greatest populist challenge to any contemporary movement to reduce automotive carbon emissions in the twenty-first century. This is one reason Paterson has joined a growing scholarly literature that interrogates this trope. See also Seiler, Republic of Drivers; Bohm, et al., Against Automobility.

19 Young, Diana and Stotz, Gertrude in Miller, Car Cultures. 
settlements dramatise the textures of the national network of tracks, roads, highways and freeways as culturally connective tissue. Journeying along these conduits allows explorations of unfolding histories beyond the normative narratives of exploration and expansion that customarily move inland from the city and the coast.

Until the age of spacious mega-motorways, travelling through virgin or cleared and fenced landscapes, passing through small towns and feeling every bump in the road were familiar experiences to anyone making land transit between Australian cities. Despite the loss of this experience in seaboard zones, thousands of Australians - many of them Aboriginal-regularly travel thousands of kilometres of unsealed, unlit roads, beyond the reach of regular mobile phone signals and far from emergency services. Fatalities are all too common and their statistics intersect dreadfully with those that describe proportionally high levels of alcohol consumption, poor road maintenance, and a rough trade in secondhand vehicles.

The history of Australia's highways, back roads and bush tracks outlines, amongst other things, a map of cross-cultural engagements. Both the walking paths of Indigenous families and the exploratory intrusions of the colonialsettler era laid the groundwork for many of the earliest routes that are today the nation's major transit corridors. The traces of the earliest colonial incursions have been reinscribed through the naming of roadways after such identities as Hume, Sturt, Stuart, Lasseter and Gregory. Perhaps it is in the less popularly known, but no less travelled, corridors of the Gunbarrel Highway and the Birdsville, Tanami and Oodnadatta 'tracks' that we sense an enormity of different passages and the diverse social identities that they convey.

As a growing number of roadside memorials are erected along our roads, scholars are beginning to revisit the consequences of automobility in terms of today and tomorrow as well as with regard to our cultural heritage. ${ }^{20}$ Automobility is, after all, a dynamic state of dangerous practices, forces and materials. The functional purpose of a car - to transport - is most vivid when operating in the extreme, hurtling down the road at high speed or lying still, stationary or broken. When a vehicle is not running, we become acutely aware of its status, not only as an icon of technological modernity, but also as a social symbol of mobility with a capacity to traverse worlds.

Many Australian readers of this volume will be familiar with Vic Hall's blackand-white 1956 photograph of Western Arrarnta painter Albert Namatjira

20 Clark, Jennifer, 2008, 'Challenging motoring functionalism: roadside memorials, heritage and history in Australia and New Zealand', The Journal of Transport History, vol. 1, no. 29, pp. 23-43. 
looking out 'somewhat bemused'21 from the driver's side window of his 'flash' new Dodge truck, the crucifix atop the Hermannsburg mission church in the background of the image poking up as if affixed to the back edge of the cabin roof, and the door panel displaying the painted inscription 'THIS VEHICLE PRESENTED BY AMPOL. Albert Namatjira. ARTIST Alice Springs'.

Namatjira's meteoric rise as a collectable landscape water-colourist in the 1950s, Aboriginal citizen of a modern nation-state and his personal demise as a broken man struggling with the costs of his modernity are public images that have entered a national narrative, carried by this image (amongst others). ${ }^{22}$ The artist's old truck now rests, rusting into the ground, in the Hermannsburg Historic Precinct.

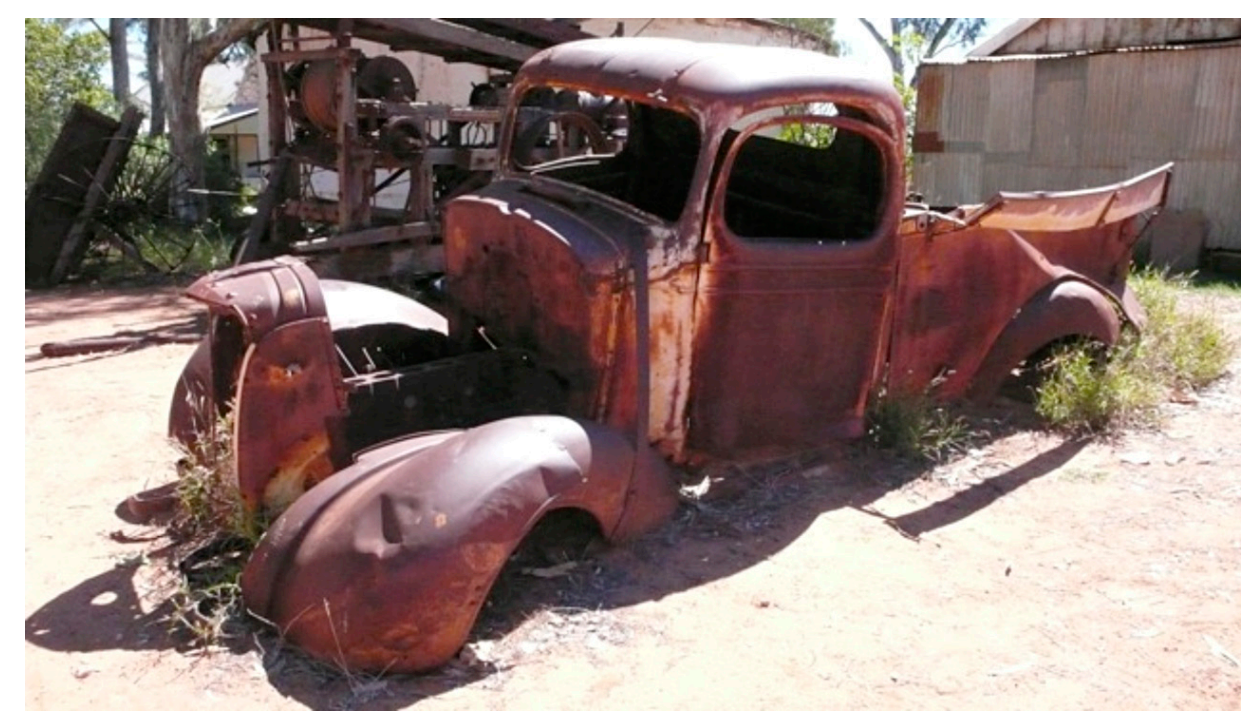

Figure 1 The ruined remains of Albert Namatjira's truck

Photograph: Lisa Stefanoff, 2010

Beneath the peeling narrative surface of this ruin are personal Arrarnta family memories of the vehicle as a space of intimate family journeys on country, comprising local history with still unimaginable 'costs'. As Namatjira's nephew Western Arrarnta singer-songwriter Warren H. Williams explained to the author

21 Croft, Brenda 2001, 'Albert's gift', [Catalogue essay], Indigenous Art, Art Gallery of Western Australia, Perth, p. 77.

22 Namatjira first exhibited his art in Melbourne in 1936. In 1945 he became the first Indigenous person to attain an entry in Who's Who in Australia. He was awarded the Queen's Coronation Medal in 1953 and presented to Queen Elizabeth 11 the following year, garnering significant media attention. Three years later, he was granted Australian citizenship. The painter died 13 years later, 'broken-spirited, crucified between two cultures' (ibid.) after spending time in jail in 1958 for supplying alcohol to a relation charged with an intoxicated murder. Some of these events have recently been dramatised in the Big hArt theatre piece Namatjira, bringing the painter's biography back into the public limelight. 
(LS), the old truck is a multi-layered place of family story, animated through memorial lyric: 'this song is about the old truck at Hermannsburg. I used to wonder where it went and how far it went. My Dad used to tell me that I used to jump on that truck and cruise around. I miss my old man. ${ }^{23}$

\section{Suw a piture seyou of you back in the Day. Can't imagine how mueh you Proped. Pard. It was good to seofory} beught the old Truet back in 46

If took you to place you wanted to Go. Famonly gow took, To Places gav'd show. The loife and you and gill of your kide In the Truek you bought back in 46

Now it's dd and Rusted sots wouncler a
Tree. Ifts there for the woul to see Yos it's dd and rusted sots under a Tree The Old Truek you Bought back in 46

Figure 2 Warren H. Williams' written lyrics 'Uncle's Truck'

Image courtesy Warren H. Williams, 2010

The essays collected in this special edition move from geographies of nonurban automobility to lived experiences of journeying in these spaces; and from representations of automobile worlds and the regenerative energies of car culture to a sobering analysis of the underside of petrol-powered modernity.

23 Personal conversation, Lisa Stefanoff, 26 May 2011. 
Georgine Clarsen's historical essay 'The Flip Side: Women on the Redex Around Australia Reliability trials of the 1950s' (Chapter 2) illuminates the relatively unknown gendered geography of non-urban car culture - that of Australian women rally drivers. ${ }^{24}$ Clarsen offers an important insight into the desire many women felt, against the backdrop of postwar adventure travelogues written largely by men, to experience those parts of Australia lying beyond the cities and towns of their upbringing. Stating that 'she wanted to see the country', ${ }^{25}$ trial driver Winifred Conway foreshadows the fantasy and now accepted norm of Australian retiree lifestyle evidenced in the 'grey nomad' phenomenon. In recognising the role that women played in the Redex trials, as well as early impulses of tourism, Clarsen forges a history of Australian adventure motoring that speaks to how gendered identities are negotiated through automobility. In doing so, she addresses how certain driving practices have been shaped by specific perceptions of masculinity (men tearing through the bush) and, recursively, how a prevailing rhetoric of gender wrought stereotypes of the driving performance of women.

Catherine Summerhayes' screen-studies piece "'Going Back": Journeys with David MacDougall's Link-Up Diary' (Chapter 3) and Anthony Redmond's anthropological contribution 'Now we got truck everywhere, we don't travel anywhere' (Chapter 4) offer analyses from the 'insides' of socially charged car journeys. From the perspectives of documentary film studies and anthropology, respectively, they explore the ways in which cars define social space and experience. We see how, confined inside cars, drivers' and passengers' bodies enter new relationships in space and time with each other and with culturally coded swathes of country. These papers illustrate, moreover, the various roles that cars have played as place-connecting containers of continuous and broken Aboriginal kinship.

Summerhayes' conversational reading of Peter Read's formative work with the Stolen Generations support organisation 'Link-Up' and David MacDougall's filmic documentation of complex family reunion journeys illustrate how automobility can be a mode of research. When witnessed by culturally distant viewers, this movie provides a trope for travelling back along the original research roads represented on screen with historical hindsight, adding an additional layer of value to the terrain traversed.

Drawing our attention to Kimberley community journeys, Redmond demonstrates the ways in which landscapes of country seen from a travelling car are intimately felt by local cruisers as sensory encounters with transforming traditions, knowledge and embodied ways of knowing. Redmond's chapter

24 But see other writing by Georgine Clarsen.

25 Georgine Clarsen, this volume. 
also offers a redress to Paterson (and related critiques), in that it shows how phenomenological accounts of automobility are not necessarily situated in the identity of the individual and its celebrated freedoms. Redmond's reading of Ngarinyin automobility is instead an account of the socially extended body. A bump in the road might be felt individually, but it also might be a shared encounter: a source for performing collective identity and a way of experiencing the land culturally.

Most Australian researchers working outside or between cities have experiences of long-distance automobility as a mode of research practice. Those of us who live in non-urban contexts are acutely familiar with the challenges and perils of long-distance road travel - car and road maintenance, speed, fatigue - and the tolls exacted on our communities by often unregulated car and vehicle culture. Our bodily engagements with motorcars take on a visceral quality when we are left to contemplate a vehicle broken into a scatter of fragments. Pam Lofts' artwork 'Country Love, Country Love, (day 1)' (Chapter 5) presents a graphic narrative tangle of fibre, metal and organic remains to illuminate the not-uncommon social and physical impacts of travel on remote Australian desert roads. Lofts' evocations of an imagined relationship arrested in the dust are part of a larger installation that draws the viewer into an encounter with the artefacts and images of other people's lives. ${ }^{26}$ Through her own material assemblage of photograph and word fragments, Lofts cleverly reconstitutes the fragmentary nature of this scene and the raw mystery it conveys. The fact that the country will eventually reclaim this story is an implicit assertion of this piece.

Lofts is not alone in picturing the 'breakdown' of material things. Another Alice Springs-based artist, Deborah Clarke, encounters car ruins as part of a local natural landscape where abandoned wrecks rust into the land, producing visual continuities with desert palettes and textures (see our cover image). Lofts and Clarke reflect something of a broader artistic sensibility that we would suggest is a thoroughly contemporary understanding of Australian landscape - a country in which 'behind the termite mounds we might find the rusting shells of abandoned cars'. ${ }^{27}$ Through their visual sensitivity to an archaeology of abandonment, such artists recognise that entropy and fecundity go hand in hand. By not isolating the modernity of the car from the fabric of an ancient ground, they present a vision of country that is dynamic, enveloping the organic and inorganic, entwining what is human made with the land. Whether grounded in observation, intuition or knowledge, these artistic renderings are in keeping with a cultural conceptualisation of country as connected and living,

26 In its original presentation, this work was constructed at a larger scale, inviting viewers to encounter the assemblage of images as one might an actual car.

27 Fox, William 2009, Wanderers in the Desert of the Real 2009, [Catalogue essay], Australian Galleries, Melbourne. 
so that even the ruins of the twentieth century might be seen as emergent forms. Such articulations of country owe much to Australian Aboriginal thought, and a growing cross-cultural respect and dialogue around what makes up the shared ground on which Australians stand. ${ }^{28}$

In her essay 'Roadworks: Automobility and belonging in Aboriginal art' (Chapter 6), archaeologist, artist and art historian Ursula Frederick takes up the notion of country as a basis for locating the 'roadworks' of four late-twentiethcentury male Aboriginal artists in relation to other Indigenous art traditions of representing place, Law, cultural knowledge, history and identity. For Frederick, artworks depicting roads are important because they tell emplaced stories about mobility, organising both narrative and visual composition. In this analysis, works by WA artists Revel Cooper and Christopher Pease respectively communicate 'the intermittence of movement of Noongar people through country' - that is, the possibility of mobility away from the historical circumstance of containment - and 'an effort to consolidate Aboriginal presence, over time, in place' in the context of dispossession. In a work that nominally heads towards the urban-Redfern in Sydney - a Lin Onus work becomes 'an image of the road as a living entity and the driving experience as awakened encounter'. Through an extended commentary on Ian Abdulla's 'vast road network' of paintings, drawings, stories and installations, Frederick argues that roadworks reveal 'the art of automobility as country' ${ }^{29}$

Turning to writing as a mode of representation, Katherine Bode examines the metaphor of driving and other automotive word-scapes created in Smoke Encrypted Whispers, a collection of poetry by multiple-award-winning writer Samuel Wagan Watson. While Watson's poetry is immersed in a specific experiential and local knowledge informed by growing up 'in Yagara country, country where there was always the smell of burnt rubber', ${ }^{30}$ his words carry a resonance that extends far beyond the city of Brisbane. As Bode points out in 'we're not truckin' around' (Chapter 7), Watson 'employs roads to symbolise colonialism and to explore its effects on Aboriginal people and culture'. His tales of automobility amplify the ambiguities of the car, the road, and driving as both a symbol of colonialism and a mode of resistance to it. Bode's analysis embraces the movement and stillness in Watson's automobility as metaphors for 'the eruption of the past into the present' and 'claiming a home', respectively.

\footnotetext{
28 See Bonyhady, Tim and Griffiths, Tom (eds), 2001, Words for Country-Landscape and language in Australia, UNSW Press, Sydney.

29 See Frederick, this volume.

30 Samuel Wagan Watson 2008, 'Writers as Readers' session, Sydney Writers' Festival (19 mins 7 secs), viewed 19 June 2011, http://www.themonthly.com.au/samuel-wagan-watson-his-influencesand-inspirations-sydney-writers-festival-1048
} 
These sentiments of haunting and hope connect the reader with other places and other crossroads ${ }^{31}$ throughout Australia, and in doing so they re-imagine notions of the nation as 'the dreaming that suddenly crawls onto the road' ${ }^{32}$

In 2009 Aboriginal filmmaker Warwick Thornton brought the scourge of petrol sniffing in Central Australia to global attention with his Cannes Film Festival Camera d'Or-winning feature drama Samson and Delilah. In 'Fuel, Cars and the Geography of Petrol Sniffing', health anthropologist Maggie Brady (Chapter 8) examines the social costs of petrol-powered 'remote' Australian automobilised modernity. Brady's ethno-historical review of petrol sniffing as a 60-yearold practice complements an emerging body of research that investigates the indirect relationship between automobility and health and safety issues. ${ }^{33}$ Brady cautions that despite the introduction of low-hydrocarbon aromatic 'Opal' fuel in some desert locations such as Alice Springs, 'frequent Indigenous journeys and circular mobility between communities and towns within and across regions present constant opportunities for the practice of petrol sniffing to be reignited'. ${ }^{34}$

In addition to the collection of essays in the present volume, the 2005 Cruising Country symposium seeded a number of other publications. These explore mobility and remote education in Maningrida, ${ }^{35}$ the role of trucks in mediating Kuninjku social worlds, ${ }^{36}$ the place of the car in contemporary culture and art, ${ }^{37}$ and the sonic archaeology of the Hume Highway. ${ }^{38}$ Creative arts collaborations and other public panels also emerged out of conversations and working partnerships elaborated at Cruising Country. ${ }^{39}$ As well as providing a platform for established scholars to share their research and contribute to a crucible of

31 Samuel Wagan Watson has spoken of the influence of 'the myth of the crossroads' and its analogy in Australia. The crossroads, in this sense, is where US blues musician Robert Johnson was famously supposed to have met and made a deal with the devil. On his influences and inspirations see Samuel Wagan Watson, 'Writers as Readers'.

32 Watson, Samuel Wagan 2004, Smoke Encrypted Whispers, University of Queensland Press, St Lucia, p. 88. 33 Dixon, Jane, Banwell, Catherine and Hinde, Sarah 2007, 'Car-centred diets, social distinction and cultural mobility: food system research directions', Food, Culture, and Society: An international journal of multidisciplinary research, vol. 10, no. 1, pp. 131-47.

34 See Brady, this volume.

35 Fogarty, William 2005, 'You got any truck?' Vehicles and decentralised mobile service-provision in remote Indigenous Australia, Working Paper No. 30, Centre for Aboriginal Economic Policy Research, Australian National University, Canberra.

36 Altman, Jon and Hinkson, Melinda 2007, 'Mobility and modernity in Arnhem Land: the social universe of Kuninjku trucks', Journal of Material Culture, vol. 12, no. 2.

37 Fuller, Glen 2006, Supercharged, [Catalogue essay], Institute of Modern Art, Brisbane.

38 Lindsey, Kiera 2007, 'Encounter and enterprise: a colonial soundtrack of the Hume Highway', in Ros Bandt, Michelle Duffy and Dolly McKinnon (eds), Hearing Places, Cambridge Scholarly Press, London.

39 Kiera, Lindsey and Podkalicka, Aneta 2006, 'Sydney Road: a world in a street', Listening Room, Produced by Ros Bandt, ABC Radio National, Sydney; Johnson, Vivien with Kean, John, Long, Jeremy and Thorley, Peter 2007, Mutukayi: Motor cars and Papunya painting, 2 December 2007, Audio transcript, National Museum of Australia, Canberra, viewed 1 June 2011, <http://www.nma.gov.au/audio/transcripts/NMA_ mutukayi_20071202.html> 
work about automobility in Australia, Cruising Country provided a forum for pre-doctoral students to present their work. ${ }^{40}$ Several emerging scholars examined histories and cultures of leisure travel in Australia, including twentieth-century overland adventures and the retiree lifestyle travel phenomenon referred to as 'S.A.D. (See Australia and Die)' and 'grey nomadism'. ${ }^{41}$

Cruising Country also encompassed a photographic exhibition at the ANU School of Art. ${ }^{42}$ A floor talk by Warlpiri 'Bush Mechanic' Francis Jupurrula Kelly and curator James Warden about the acquisition by the National Museum of Australia (NMA) of the infamous Bush Mechanics' EJ 'blue car' Holden ${ }^{43}$ (Figure 3) accompanied a public program of film screenings and discussions held at the museum. ${ }^{44}$ This concentration of screen work highlighted the relatively longestablished national cinematic social imaginary with non-urban automobility at its heart - a theme that dominated Australian automobility scholarship at the time. ${ }^{45}$

Australian cinema has rendered the practices and experiences of cruising country most visible for broad audiences through the narratives of what Fiona Probyn-Rapsey calls 'bitumen films' ${ }^{46}$ Our road-based social dramas-from Mad Max (1979) and Priscilla Queen of the Desert (1994) to Japanese Story (2003)often travel out into the non-urban from the fringes of our concentrated coastal populations and cultures. Whilst there is a considerable literature identifying

40 Yabsley, Louise 2005, I still call a trailer home... a history of grey nomads, unpublished BA Hons Thesis, University of Sydney, NSW.

41 Hall, Laina 2006, "The "zest of adventure" in Australian overland narratives, 1920-2000', Journal of Tourism and Cultural Change, vol. 4, no. 2, pp. 85-95; Holloway, Donell 2007, 'See Australia and die: shifting discourses about gray nomads', Tourism Culture \& Communication, vol. 7, no. 3, pp. 161-8.

42 'rust, dust... and other places': Deborah Clarke, Ted Deveson, Ursula Frederick, Katie Hayne, Pamela Lofts, Lisa Stefanoff, Bronwyn Wright.

43 Bush Mechanics (David Batty and Francis Jupurulla Kelly 1998, < http://www.rebelfilms.com.au/bushmechanics.html>) first hit Australian television screens in 1999 on ABC TV, winning an Australian Film Institute Open Craft Award that year. It was followed by a four-part series of the same name in 2001 (Film Australia/Warlpiri Media Association/ABC TV). ‘The blue Holden used in Episode 1-Motorcar Jgutju (Good Motorcar) - belonged to Francis Kelly and was his personal favourite. Francis was adamant that the "blue car" be used in the series, and Episode 1 was written specifically with this in mind. As the episode shoot approached, the car had "gone bush", and David and Francis spent quite a bit of time travelling around the desert looking for it. When the car was finally located it was in fairly dodgy mechanical condition, especially the gearbox. In true Bush Mechanics style, another gearbox was taken from an old wreck and fitted in the blue car, but it now only drove in third gear. When the car eventually returned to the community with the roof hacked off, it was greeted with cries of "wiyarrpa" or "poor thing!", followed by much discussion about how to reattach the roof. Even after all it had been through, it was still considered "motorcar ngutju"' (Bush Mechanics, Film Australia press kit). See also Clarsen, 'Still moving'.

44 Confessions of A Headhunter (Sally Riley, 2000), Cold Turkey (Steven McGregor/CAAMA Productions, 2002), Link-Up Diary (Peter Read and David MacDougall, 1987), No Way to Forget (Richard Frankland/Golden Seahorse Productions, 1996), Wrong Side of the Road (Ned Lander/Graeme Issac, 1981), Freedom Ride (Rachel Perkins, 1993), and Our Community (Sean Kennedy/Frances Peters-Little, 2006).

45 Arguably, film and television studies continue to be a strong focus of Australian automobilities scholarship. Early examples include Morris, 'White panic or Mad Max and the sublime'; Clarsen, 'Still moving'.

46 Probyn-Rapsey, Fiona 2006, 'Bitumen films in postcolonial Australia', Journal of Australian Studies, vol. 88, pp. 97-109. 
the US road movie as a 'liberty' genre with its genesis in the cavalier spirit of the Hollywood western, Australian cinematic representations of the road have generated commentary equally attuned to the dystopian qualities of the road. The Cruising Country symposium also generated a paper exploring the contemporary gothic of Australian road movies. ${ }^{47}$

In the past decade, Indigenous filmmakers - in particular, those based in the Northern Territory-have created bitumen tales that provide post-colonial cultural and class commentary on the dramas of nihilistic masculine flights into oblivion. ${ }^{48}$ Others have used the road to document the journey to recover identity and family, ${ }^{49}$ or as a space for culturally identified comedy. ${ }^{50}$ The study of Australian screen culture continues to be a fruitful area of inquiry. ${ }^{51}$ As a rich site for the representation of non-urban automobility, film complements other sources and stories concerned with interrogating automobility's role in narratives of national identity. This volume goes some way towards understanding the cultural capital of automobility in Australia, and its representation in poetry, visual art, film, print media and oral history. Other directions emerging in contemporary Australian automobility research include a greater attention to health and safety, ${ }^{52}$ tourism and recreation studies $^{53}$ and the environmental consequences of automobile use. ${ }^{54}$

By no means a synthesis, this volume nevertheless marks a significant beginning. It contributes an important new voice to twenty-first-century scholarship of car cultures and automobility - one that explicitly engages with the non-urban experience. The scholars who have contributed to this edition of Humanities Research have begun the task of examining how non-urban automobility is lived and represented as a key dynamic of contemporary Australian social and cultural life. This research promises further travel. We look forward to seeing the horizon broadening as the journey continues.

\footnotetext{
47 Luckman, Susan 2010, 'Road movies, national myths and the threat of the road: the shifting transformative space of the road in Australian film', International Journal of the Humanities, vol. 8, no. 1, pp. 113-26.

48 See, for example, McGregor, Cold Turkey; Thornton, Samson and Delilah.

49 Yellow Fella (Ivan Sen, 2005).

50 Stone Bros. (Richard Frankland, 2009).

51 Harris, M. 2006, 'Desert training for whites: Australian road movies', Journal of Australian Studies, vol. 86, pp. 99-110; Johinke, Rebecca 2009, 'Not quite Mad Max: Brian Trenchard-Smith's Dead End Drive-In', Studies in Australasian Cinema, vol. 3, no. 3, pp. 309-320.

52 For example, Dixon, et al., 'Car-centred diets, social distinction and cultural mobility'.

53 For example, Taylor, Andrew and Carson, Dean 2011, 'Four-wheel-drive tourism in desert Australia: the charge of the "might" brigade?', in Bruce Prideaux and Dean Carson (eds), Drive Tourism: Trends and emerging markets, Advances in Tourism, Routledge, Abingdon and New York, pp. 224-45.

54 Larson, Silva and Herr, Alexander 2008, 'Sustainable tourism development in remote regions? Questions arising from research in the north Kimberley, Australia', Regional Environmental Change, vol. 8, no. 1, pp. 1-13; Simpson, Catherine 2009, 'Cars, climate and subjectivity: car sharing and resisting hegemonic automobile culture', M/C Journal, vol. 12, no. 4.
} 


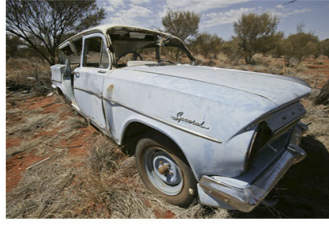

nma.img-ci20031008-021...

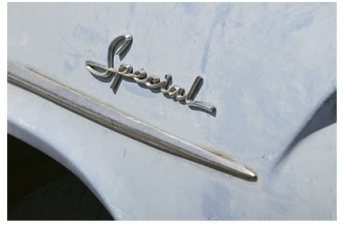

nma.img-ci20031008-025...

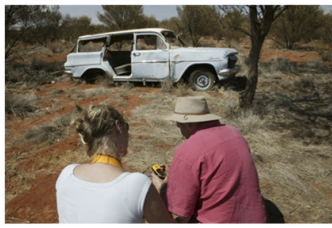

nma.img-ci20031008-037..

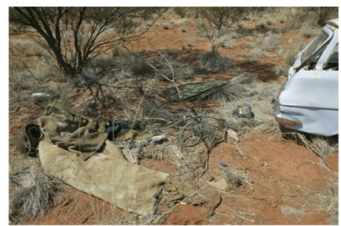

nma.img-ci20031008-042...

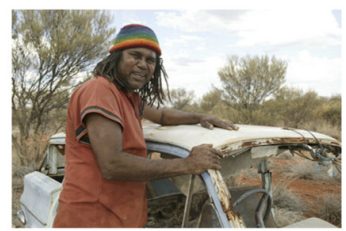

nma.img-ci20031008-052...

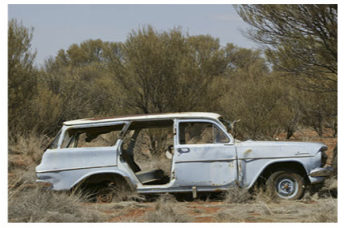

nma.img-ci20031008-022...

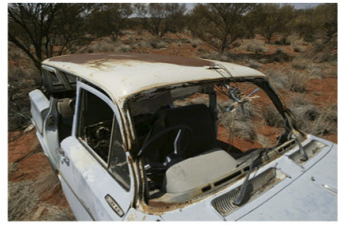

nma.img-ci20031008-029...

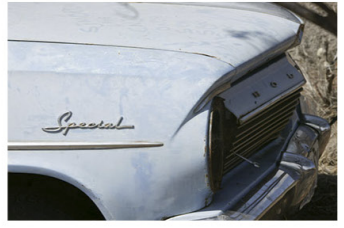

nma.img-ci20031008-024...

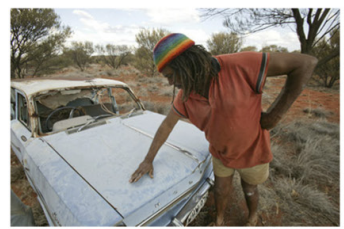

nma.img-ci20031008-066...

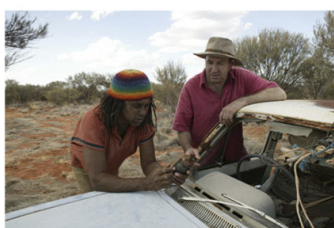

nma.img-ci20031008-054...

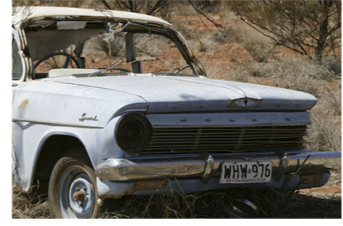

nma.img-ci20031008-023...

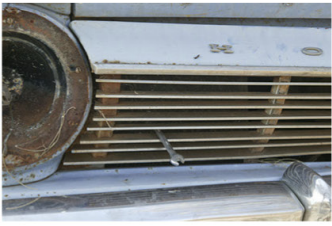

nma.img-ci20031008-030...

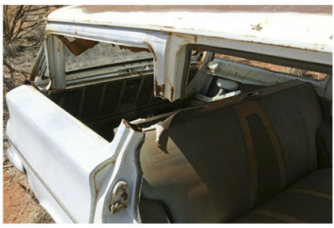

nma.img-ci20031008-043...

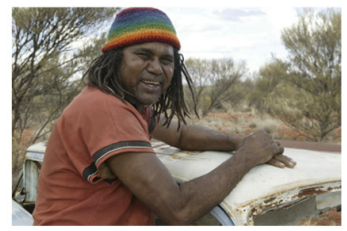

nma.img-ci20031008-051...

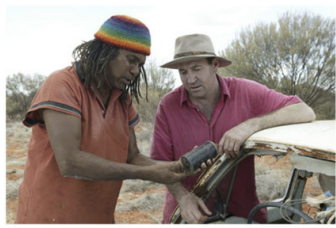

nma.img-ci20031008-056...

Figure 3 Contact sheet of images taken by National Museum of Australia's photographer, George Serras, in 2003 during the acquisition of Francis Jupurrurla Kelly's EJ Holden station wagon for the museum's exhibition Extremes: Survival in the Great Deserts of the Southern Hemisphere 
We would like to thank the contributing writers and reviewers for their work in bringing this volume together. Our deep appreciation to Karen May, Jan Borrie, the Humanities Research Board and staff at ANU E Press for shepherding this process over a long time. Special thanks goes to Deborah Clarke for allowing us to reproduce her artwork 'After the Rain', on the cover of the journal. As mentioned, this volume was seeded by a symposium, film-screening series and art exhibition held at The Australian National University and National Museum of Australia in May 2005. The event was sponsored by the Centre for Cross-Cultural Research, ANU, with additional funding assistance for speakers provided by the ANU Centre for Aboriginal Economic Policy Research and Arts NT.

We would like to acknowledge, in addition to the many attendees who provided stimulating questions and conversation, the many individual speakers, artists, filmmakers and musicians who contributed to making Cruising Country 2005 a successful program of events: Jon Altman, Diane Austin-Broos, Ros Bandt, Peter Bartlett, Jennifer Biddle, Deborah Clarke, Georgine Clarsen, Sharon Condren, Ann Curthoys, Ted Deveson, Bill Fogarty, Alison French, Glen Fuller, Laina Hall, Katie Hayne, Melinda Hinkson, Donnell Holloway, Matilda House, Graeme Issac, Vivien Johnson, Francis Jupurrula Kelly, Kiera Lindsey, Pamela Lofts, Jeremy Long, Susan Luckman, David MacDougall, Steven MacGregor, Charles Merewether, Hamish Morgan, Howard Morphy, David Nash, Frances Peters-Little, Nicolas Peterson, Noah Pleshet, Peter Read, Anthony Redmond, Catherine Summerhayes, James Warden, Katharine Willis, Bart Willoughby, Bronywn Wright, and Louise Yabsley. We are grateful to the filmmakers Richard Frankland, David MacDougall, Graeme Issac, Steven MacGregor, Rachel Perkins, Frances Peters-Little and the artists Deborah Clarke, Ted Deveson, Ursula Frederick, Katie Hayne, Pamela Lofts, Lisa Stefanoff and Bronwyn Wright for exhibiting their work. James Henry Little and his band produced some great sounds during the symposium dinner. Thanks also go to staff at the Centre for Cross-Cultural Research, in particular Celia Bridgewater, Suzanne Groves, Howard Morphy and Anne-Marie O'Brien. 